
sytecie Lubelskim Jana Pawła II, doktorantka w Katedrze Historii

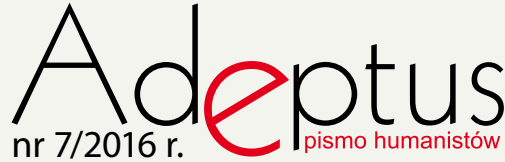
Języka Angielskiego i Translatoryki w Instytucie Filologii Angielskiej Wydziału Nauk Humanistycznych KUL. Jej zainteresowania badawcze koncentrują się wokół historycznych tłumaczeń Psałterza na języki francuski i angielski, ze szczególnym uwzględnieniem warstwy leksykalnej tekstów. Przygotowuje rozprawę doktorską dotyczącą doboru rzeczowników w czternastowiecznych średnioangielskich tłumaczeniach Psalmów prozą.

kinga.lis@kul.pl

\title{
Kinga Lis
}

\section{The soul in the mediaeval Psalter}

\section{Introduction}

$\mathrm{t}$ is not an exaggeration to state that the Psalter has occupied a central position in Western Christian devotion for centuries, as far as both individual and congregational practices are concerned. ${ }^{1}$ There is no other single book of the Bible that has been copied and translated so frequently. Although present-day scholars do not agree as to whether Psalms "were always intended to be sung" (Sutherland, 2015, p. 1) or whether the practice gained currency only in the 3 rd century as a counterweight to the heterodox hymns which were in use, ${ }^{2}$ there is no doubt that already in the Middle Ages their pre-eminent position was unquestioned.

The special place of the Psalter stems from its exceptional character:

The Psalms not only reflected the joy and sadness of David's own life, with its oscillations between conquest, sickness, betrayal, divine intervention, despair, infidelity, joy and steadfastness; the Psalms were also seen as a true compendium of Christian theology, words of praise for the Triune God, a sure guide for an upright life, and a vast

\footnotetext{
${ }^{1}$ For a panoramic view of the place occupied by the Psalter in the Middle Ages, see the volume edited by van Deusen (1999).

${ }^{2}$ This view is part of the so-called new consensus. Within the earlier theory concerning Psalm singing, "it was assumed that Christians used the Psalter as the hymn book from the beginning" and "they did so in direct continuity with the practice of the Synagogue" (McKinnon, 1999, p.44). Interestingly, there is no agreement as to the validity of the latter part of this statement either (McKinnon, 1999, pp.45-46).
} 
collection of poetic texts that could become one's own personal words of prayer in all seasons and conditions of the human pilgrimage through this life (Zinn, 1999, p. xii).

The appeal of the Psalter is thus a reflection of its character - it was relevant for people of all walks of life. And yet, despite its being the text closest to the heart, it was at the same time venerated as a sacred text, which means that the approach to its translation was as strict as that to the translation of any other part of the Bible.

Both these factors, i.e. the sacred character of the text and its universal relevance, shaped the spirit of the mediaeval vernacular Psalter and can indeed be said to lie at its heart and soul. In this paper, I attempt to investigate their practical applications through an analysis of renderings of four Latin nouns in the first fifty Psalms of six mediaeval Psalter translations: four ME texts Richard Rolle's Psalter, Middle English Glossed Prose Psalter, the Psalters of the Early and Late Wycliffite Bibles, all from the 14th century; a 15th-century French Psalter; and a 12th-century Anglo-Norman translation of the Psalms. The nouns chosen for the purpose are those most central to the texts: anima, animae 'soul,' cor, cordis 'heart' and, perhaps surprisingly, ren, renis 'kidney' and lumbus, lumbi 'loins,' since in the biblical context they convey the notions of the 'seat of the emotions, passions, heart' and 'seat of emotion, love, ${ }^{3}$ respectively. The analysis of their treatment in the discussed translations and, more precisely, of any divergences in their renderings constitutes the core of the paper (Section 3). The information concerning the translation theory with respect to biblical texts and its application in the case of each of the analysed texts which is necessary for the correct interpretation of the data is discussed in Sections 2.1 and 2.2, respectively. The last section constitutes a conclusion to the study.

\section{The heart and soul of the Psalter}

\subsection{Mediaeval translation theory with respect to biblical texts}

The dominant mediaeval approach to translation was in general inherited from the Antiquity and as such was the one advocated for already by Marcus Tullius Cicero (106-43 BC). Cicero, while discussing the need for his translation of "the most famous orations of the two most eloquent Attic orators, Aeschines and Demostenes" (Cicero, after Munday, 2009, p. 1) in his treatise De optimo genere oratorum, states straightforwardly:

\footnotetext{
${ }^{3}$ The meanings of ren, renis 'kidney' and lumbus, lumbi 'loins' presented here have been adopted after the contextual definitions offered in the Middle English Dictionary for their renderings into ME in the verses of the texts discussed in this paper. See entries for kide-nēre 'kidney' (meaning c), lēnd(e 'loins' (meaning 2b), nēr(e 'kidney' (meaning c), reine 'kidney' (meaning 2a).
} 
I did not translate them as an interpreter but as an orator keeping the same ideas and the forms or as one might say, the 'figures' of thought, but in language which conforms to our usage. And in so doing, I did not hold it necessary to render word for word, but I preserved the general style and force of the language (Cicero, after Munday, 2009, p. 1).

One of the most prominent mediaeval supporters and practitioners of this approach was Saint Jerome, who used the authority of Cicero, among others, to fend off accusations of errors in his rendition, which he feared would ensue from his lack of adherence to the method of straightforwardly literal translation. And yet, as argued by Copeland (1989), Jerome misappropriated the terminology proposed by Cicero. Jerome's interpretation of Cicero's words led him to conclude that in the course of translation, unquestioned priority should be accorded to the message and not to the letter - in service to the source text, whereas in the Roman world, the superiority of "the general style and force of the language" stemmed from the perception of translation as being in service to the target language - translation was meant to replace the original and not to serve it. It was, however, Jerome's defective understanding of Cicero's words that survived into the Late Middle Ages (Sutherland, 2015, p. 68).

This sense-for-sense translation advocated for so strongly was applicable in all contexts with the exception of the one pertinent to this study - the biblical context. The reason for this was that the status of the text in question outranked by far those of any other texts. The exceptional treatment bestowed upon the translation of the Bible or any of its parts is made bluntly clear in Jerome's letter to senator Pammachius, entitled De optimo genere interpretandi (395):

In the above remarks I have assumed that I have made alterations in the letter and that a simple translation may contain errors though not wilful ones. As, however the letter itself shows that no changes have been made in the sense, that nothing has been added, and that no doctrine has been foisted into it, 'obviously their object is understanding to understand nothing'; and while they desire to arraign another's want of skill, they betray their own. For I myself not only admit but freely proclaim that in translating from the Greek (except in the case of the holy scriptures where even the order of the words is a mystery ${ }^{4}$ ) I render sense for sense and not word for word (Jerome, n.d.).

This split in the approach to the task of translation depending on the nature of the text into the word-for-word and sense-for-sense attitudes became an inherent part of

\footnotetext{
${ }^{4}$ Emphasis mine.
} 
any discussion of biblical translation and still finds its proponents. On the whole, though, in the Middle Ages

[t]he dominant theory of Biblical translation, based on Jerome's discussion of this specialized task rather than on his consideration of translation in general, accepted the principle that every word of the text was sacred: even the order of the words is a mystery, and this mystery must be preserved in translation (Hargreaves, 1965, p. 123).

\subsection{Mediaeval translation theory in practice}

The deeply ingrained need for fidelity to the source text is almost palpable throughout the history of mediaeval biblical translations into English and French, whose fates are inextricably interwoven. To start with, it accounts for the practice of glossing pervasive in Anglo-Saxon England, which in turn testifies to the need for Scripture in the vernacular. In the wake of the Norman Conquest, whose one long-term consequence was the undermined position of the English language, there were "no efforts [...] made during the thirteenth and earlier fourteenth centuries to update or recreate the substantial OE prose translations [...] or to add further biblical books to them" (Marsden, 2011, p. 283). Despite the fact that the interval in the production of the vernacular renditions of the biblical texts did not mean a complete lack of access to Christian literature, ${ }^{5}$ it did mean that direct access to the Bible was not granted to the lay - a gap the mediaeval ME Psalter translations analysed here (among other types of publications) were intended to fill. In the meantime, however, the precedent set by the Anglo-Saxon tradition of vernacular glossing provided grounds for the initiation of such efforts in the French language (Rector, 2009, 2010), as it does not appear to be a coincidence that the first biblical renditions into French date from the 12th century and are of Anglo-Norman origin. The French language in use on the Continent lacked the prestige which Anglo-Saxon used to enjoy and which made the latter a suitable medium for the renditions of the sacred texts. Even though the English language itself had by then lost this elevated status, "one of the longest continuous traditions of biblical translation of any of the modern Western languages" (Marsden, 2011, p. 272), i.e. that created in Anglo-Saxon England, was more than sufficient to encourage the creation of the first Insular French renditions, which

\footnotetext{
${ }^{5}$ As explained in Marsden (2011, p. 284), "later twelfth, thirteenth and fourteenth centuries saw the production of an astonishing quantity and variety of Christian devotional, instructional, and regulatory literature."
} 
were soon followed by dozens of Continental French ones. Thus, it might be postulated that the Anglo-Saxon tradition was alive in French translations during the time when the anxiety about the status of the English language prevented, it appears, the idea of putting the vernacular to such a use from even entering the English minds. The English were, however, well aware of the plethora of French translations (St-Jacques, 1989, p. 137) and in due time, in the 14th century, renewed efforts in this area could be witnessed also in England.

The texts I analyse in this study are all mediaeval biblical renditions to which the rule of literalness discussed above should apply and the fact that they implement the principles of the period's translation theory in different ways is thus particularly striking. Let me begin with probably the earliest of the English translations to be discussed here, Richard Rolle's Psalter (henceforth RRP), dated approximately to the second quarter of the 14th century (cf. e.g. Bramley, 1884, pp. v-xvi; Allen, 1988, p. 65; St-Jacques, 1989, p. 136). Even a cursory examination of its text leaves the reader in no doubt as to its compliance with the principles of word-for-word translation advocated by Jerome in the case of scriptural renditions. This feature of the translation attracted much criticism from modern scholars, for whom the resultant rendition "in its slavish adherence to the Latin original gives more the impression of a gloss than a translation" (Paues, 1902, p. Ix). ${ }^{6}$

However, when approached from the perspective of the expected fidelity, ${ }^{7}$ it must be admitted that "[t]he manner of Rolle's translation not only respects the authority of the original and follows in established traditions, but it also (theoretically at least) serves the needs of an audience wanting, for perhaps none other than practical reasons, to follow the cadences of the Latin Psalter" (Sutherland, 2015, p. 76). This approach did not allow for stylistic considerations to be superimposed on it as the Psalter was no place for concessions made to literary deliberations because it endangered the orthodoxy of the translation. Nevertheless, despite the fact that in Rolle's translation policy primacy was given to preserving the literal reading, the readers' moral elevation was also catered for - in the Commentary on the text. Thus, by means of separating them, Rolle managed to provide for both literal accuracy - so important in the context of biblical translation and clarity of the conveyed message.

\footnotetext{
${ }^{6}$ For critical views on the linguistic layer of RRP, see Wells (1916, p. 402); Deanesly (1920, p. 145); Hargreaves (1965, p. 126); and Norton (2000, p. 5).

${ }^{7}$ In this context see also Charzyńska-Wójcik (2013, pp. 76-77).
} 
A resemblance to RRP in the degree of literalness is to be found in the Psalter of the Early Version of the Wycliffite Bible ${ }^{8}$ (henceforth EV), dated to the last quarter of the 14th century (cf. e.g. datings given in Wells, 1916, p. 466; Fowler, 1960, p. 96; Lindberg, 1989, p. 74; Dove, 2006, pp. 386-388; Charzyńska-Wójcik, 2013, p. 86). Although the manuscript copies of EV do not contain the Latin text rendered in the translation, ${ }^{9}$ they follow it closely and thus, as put harshly by Norton (2000, p. 7), "only the absence of the Latin prevents [EV] from being an interlinear gloss".

A rendition which contests this traditional Jeromian attitude to biblical translation, paradoxically using Jerome as an advocate of the sense-for-sense approach in which the meaning is superior to the form, is the so-called Late Wycliffite Bible (LV), also dating from the last quarter of the 14th century (cf. Forshall \& Madden, 1850, p. xxiv; Fowler, 1960, p. 97; Lindberg, 1989, p. 74; Dove, 2006, pp. 388, 392). Its aim and the process of translation are described in the General Prologue to LV, whose author gives the reader the impression that the translation was made from scratch. However, a closer analysis of the two renditions, i.e. $\mathrm{EV}$ and $\mathrm{LV}$, demonstrates that the extent of convergence between them is too great to speak of two independent translations. ${ }^{10}$ There is no agreement in the relevant literature as to how successful LV was in attaining its goals related to the sense-for-sense approach, although there is no doubt that when juxtaposed with $\mathrm{EV}$, it compares favourably despite the improvements not being striking.

The last of the ME renditions I analyse in this paper is the Middle English Glossed Prose Psalter (MEGPP), ${ }^{11}$ a text contemporaneous with RRP (early 14th century; cf. dating in Bülbring, 1891, p. vi; Paues, 1902, p. Ivi; St-Jacques, 1989, p. 136; Hanna, 2003, p. 144). It is in fact a translation which, at the face of it, contravenes all that has been said about the strict faithfulness of mediaeval translations to the original. The Psalter is a rendition of a Latin glossed text, probably via a French and Anglo-Norman intermediaries. Since, as

\footnotetext{
${ }^{8}$ The name of John Wycliffe is inextricably connected with both the Early and Late Versions of the so-called Wycliffite Bible, although the actual extent of his involvement in the translation is a matter of an ongoing debate. For more information, see Charzyńska-Wójcik (2013).

${ }^{9}$ It needs to be added, however, that the precise manuscript which constituted the Latin source text has not been identified so far "and considering the multitude of circulating manuscripts of the Vulgate, where there are all sorts of corruptions, it seems doubtful that it can ever be identified" (Charzyńska-Wójcik, 2013, p. 45).

${ }^{10}$ See Lis (in press).

${ }^{11}$ Two manuscript copies of this text are analysed in the paper, based on Bülbring's (1891) detailed edition of the text. Such a step was taken due to the fact that $10 \%$ of the nominal choices in the first fifty Psalms diverge between these two copies (Lis, 2015), which gives one ground to treat them independently. The manuscripts in question are MS Additional 17376 kept in the British Library in London (MEGPP L) and MS 69 preserved in Dublin, Trinity College (MEGPP D).
} 
discussed above, glossing was in widespread use, this trait does not in itself appear to make the text extraordinary. However, the glosses present in this rendition are indeed extraordinary, both in the manner in which they are inserted into the text and in the way they are treated in translation. These are not interlinear or marginal glosses. Nor are they in any way set apart from the sacred text. They are incorporated into the text, and, what is even more extraordinary, in the course of the translation they usually replace the original reading of the Psalms. Such a practice appears to be straightforwardly heterodox and yet the translation has never been condemned as such and the text is preserved, apart from the ME rendition, also in its Anglo-Norman and French counterparts. ${ }^{12}$ I would like to argue, however, that heterodox as they may seem, the glosses are in fact a means to the same end as the one pursued by the translators of the remaining Psalters. Their aim is to ensure orthodoxy of the message of the text, even at the cost of not only relaxing - as was the case with LV - but often doing away with the faithfulness to the letter. The character of the glossing itself makes it reasonable to suppose that its unambiguous readings were meant to serve the needs of an exposition for those unacquainted with the biblical exegesis:

Interpretations [...] are likely, in the mind of the translator, to have been justifiable as faithful reproduction of the 'true' literal meaning of the Psalter. [...] Eliding translation and commentary into one activity, the Prose Psalter and its glossed sources have reproduced not what the psalmist said but what he meant (Sutherland, 2015, p. 127).

As regards the relationship between the different language versions of the text, it is also a matter of dispute and some would see the ME Psalter as a rendition of the French rather than Latin text (Reuter, 1938). ${ }^{13}$ However, as I do not wish to enter this discussion here, let me just remark that the close affinity between the texts is undeniable, which necessitates an analysis of the French translation in the context of its ME counterpart. ${ }^{14}$

\footnotetext{
${ }^{12}$ As stated above, the ME translation was preceded by the Anglo-Norman and French renditions, single manuscript copies of which have survived (cf. Footnote 14 below). The juxtaposition of the French and ME language versions of the text allowed researchers to establish that they stem from the same original Latin source text, see for instance the discussion in Black and St-Jacques (2012). As regards the Anglo-Norman language version, its close correlation with the French and ME translations is presented in Sutherland (2015).

${ }^{13}$ For more information on the Psalter and the relationship between the French and English versions, see Black and StJacques (2012).

${ }^{14}$ The French text analysed for the purposes of the paper comes from MS fonds français 6260, preserved in Bibliothèque nationale de France. It has to be admitted that an investigation into the preserved Anglo-Norman rendition would benefit the study, but having no access to the text - the only extant copy that I know of, the so-called Tywardreath Psalter, being stored in the British Library, MS Add. 44949 - I cannot attempt one.
} 
Finally, I have also mentioned an Anglo-Norman Psalter as subject to analysis in this paper. Its incorporation into the study should not be surprising given what has already been said with respect to the complex English-French biblical translation history, but there is also an additional reason for its presence here. Rector (2010, p. 25), upon discussing Anglo-Norman Psalter renditions, states with respect to the earliest of them the Montebourg Psalter (first half of the 12th century) - that it "served as the base for the Middle English Glossed Prose Psalter". ${ }^{15}$ It might be that the supposition is grounded only on the interwoven history of English and French translations, in which case its traces would be visible in all the 14th-century Psalters discussed here. Yet, the idea is especially alluring in the context of MEGPP, since the Montebourg Psalter remained the rendition of the Book of Psalms used in almost all French biblical translations up to the 16th century (Berger, 1884) ${ }^{16}$ and as such its influence should be detactable in the Middle French Glossed Psalter (MFGP) under analysis here and thus be felt particularly strongly in MEGPP.

\section{Soul in the Psalter}

The second part of the paper is, as stated in the Introduction, concerned with illustrating how the two features lying at the heart and soul of the mediaeval Psalter - i.e. its sacred character on the one hand, and its relevance for people of all walks of life on the other hand - can be discerned through particular word-choices in its mediaeval vernacularisations, whose aim was to bring the venerated text closer to the people, while at the same time assuming a subservient role of the translations with respect to the Latin Psalter. The latter was reflected in the faithfulness of the translation, which could, however, be interpreted in two ways (cf. Section 2). As indicated in the Introduction, in the course of the analysis I concentrate on only four Latin lemmata and their target language equivalents attested in the first fifty Psalms of the renditions studied here: anima, animae 'soul,' cor, cordis 'heart,' ren, renis 'kidney' and lumbus, lumbi 'loins.' The data are presented below, in Table 1, with the numbers in the brackets providing information concerning the number of occurrences of each item.

${ }^{15}$ Rector (2010, p. 25) puts the proposal forward on the authority of St-Jacques (1989), in whose work, however, I cannot find an explicit statement to this effect.

${ }^{16}$ For an account of the translations independent of the Montebourg Psalter, see Rector $(2009,2010)$. 
In the course of the paper I attempt to investigate their practical applications through an analysis of renderings.

TABLE 1: The data ${ }^{17}$

\begin{tabular}{|c|c|c|c|c|c|c|c|c|c|}
\hline Latin & \multicolumn{4}{|c|}{ anima, animae $(54)^{* 1}$} & \multicolumn{2}{|c|}{ cor, cordis $(63)^{* 2}$} & $\begin{array}{l}\text { lumbus, } \\
\text { lumbi }(1)^{* 3}\end{array}$ & \multicolumn{2}{|c|}{ ren, renis $(3)^{* 4}$} \\
\hline RRP & \multicolumn{4}{|c|}{ soul(e (54) } & \multicolumn{2}{|c|}{ herte (63) } & lēnd(e (1) & \multicolumn{2}{|c|}{ nēr(e (3) } \\
\hline EV & soul(e (52) & \multicolumn{3}{|c|}{$\begin{array}{l}\text { liff }(2) \\
3.2,7.5\end{array}$} & \multicolumn{2}{|c|}{ herte (63) } & lēnd(e (1) & \multicolumn{2}{|c|}{ reine (3) } \\
\hline LV & soul(e (47) & \multicolumn{3}{|c|}{$\begin{array}{c}\text { lif }(7) \\
16.14,21.20,30.9,30.17,34.4,37.12 \\
43.27\end{array}$} & herte (62) & $\begin{array}{c}\text { soul(e (1) } \\
32.15\end{array}$ & lēnd(e (1) & \multicolumn{2}{|c|}{ reine (3) } \\
\hline MEGPP L & \multicolumn{2}{|c|}{ soul(e (51) } & $\begin{array}{l}\text { pǒustē (1) } \\
40.2\end{array}$ & $\begin{array}{l}-(2) \\
15.10 \\
48.8\end{array}$ & herte $(61)^{* 5}$ & $\begin{array}{l}\text { soul(e (1) } \\
36.16\end{array}$ & $(!)^{* 6}$ ? bak $(1)$ & $\begin{array}{l}\text { reine (1) } \\
7.10\end{array}$ & $\begin{array}{c}\text { kide-nēre } \\
\text { (2) }\end{array}$ \\
\hline MEGPPD & soul(e (50) & $\begin{array}{c}\text { herte }(1) \\
9.24\end{array}$ & $\begin{array}{c}\text { pǒuēr(e (1) } \\
40.2\end{array}$ & $\begin{array}{l}-(2) \\
33.22 \\
48.8\end{array}$ & herte (62) & $\begin{array}{c}\text { soul(e (1) } \\
36.16\end{array}$ & lēnd(e (1) & $\begin{array}{c}\text { reine }(1) \\
7.10\end{array}$ & $\begin{array}{c}\text { kide-nēre } \\
\text { (2) }\end{array}$ \\
\hline MFGP & \multicolumn{2}{|c|}{ ame (51) } & $\begin{array}{c}\text { puissance (1) } \\
40.2\end{array}$ & $\begin{array}{c}-(2) \\
3.2 \\
34.16\end{array}$ & coeur (62) & $\begin{array}{c}\text { ame (1) } \\
36.16\end{array}$ & rein (1) & \multicolumn{2}{|c|}{ rein (3) } \\
\hline $\begin{array}{l}\text { Anglo- } \\
\text {-Norman }\end{array}$ & \multicolumn{4}{|c|}{ alme (54) } & \multicolumn{2}{|c|}{ coer (63) } & lumblil (1) & \multicolumn{2}{|c|}{ reins (3) } \\
\hline
\end{tabular}

${ }^{* 1}$ The noun anima, animae 'soul' appears 54 times in the text of the first fifty Psalms in the following verses: 3.2, 6.3, 6.4, $7.2,7.5,9.24,10.1,10.6,12.2,15.10,16.11,16.14,18.8,21.20,21.32,22.2,23.4,24.1,24.14,24.21,25.9,26.18,29.3,30.9,30.11$, $30.17,32.19,32.20,33.2,33.22,34.3,34.4,34.8,34.10,34.14,34.16,34.20,34.28,37.12,38.15,39.19,40.2,40.4,41.1,41.2,41.4$, $41.6,41.8,41.16,42.5,43.27,48.8,48.16,48.19$.

*2 The noun cor, cordis 'heart' appears 63 times in the text of the first fifty Psalms in the following verses: 4.3, 4.5, 4.7, 5.10, $7.10,7.11,9.1,9.28,9.34,9.36,9.41,10.2,11.2$ (x2), 12.2, 12.6, 13.1, 14.3, 15.9, 16.4, 18.9, 18.15, 19.4, 20.2, 21.14, 21.27, 23.4, $24.18,25.2,26.5,26.13,26.20,27.4,27.9,30.15,30.31,31.14,32.11,32.15,32.21,33.18,34.28,35.11,36.4,36.15,36.16,36.33$, 37.8, 37.10, 38.4, 39.11, 39.13, 39.17, 40.6, 43.20, 43.23, 44.1, 44.7, 45.2, 47.12, 48.3, 50.11, 50.18.

$*^{3}$ The noun lumbus, lumbi 'loins' appears only once - in verse 37.7 - in the text of the first fifty Psalms.

${ }^{*} 4$ The noun ren, renis 'kidneys' appears three times in the text of the first fifty Psalms in the following verses: 7.10, 15.7, 25.2.

${ }^{* 5}$ One occurrence - in verse 7.11 - had to be excluded as, according to the information in Bülbring (1891), it is spelled in a manner which prevents it from being lemmatised to herte 'heart'.

*6 According to Bülbring (1891), MEGPP L reads uaches in this passage.

As evident at a glance, RRP is faithful to the reading of the Latin source text to the letter and there is a clear one-to-one correspondence between the source and target language lemma in each case. The finding is not surprising taking into account what is known about the literalness of this translation. Rolle's Psalter is a perfect reflection of Jeromian attitude towards biblical translations and thus the adoption of the static equivalent selection

\footnotetext{
${ }^{17}$ The lemmata provided in the table come from the following sources: for Latin, from Whitaker's dictionary; for ME, from the Middle English Dictionary; for Middle French, from Dictionnaire du Moyen Français and for Anglo-Norman, from the Anglo-Norman Dictionary.
} 
strategy ${ }_{1}^{18}$ especially in the case of nouns so central to the Psalter, is to be expected in this case. The only other Psalter exhibiting such a perfect one-to-one matching with respect to the source text is the 12th-century Anglo-Norman Montebourg Psalter. Once the early dating and the inspiration with the Anglo-Saxon glossing practice are introduced into the equation, this stability in its equivalent selection procedure is a logical outcome. The remaining texts, i.e. EV, LV, two manuscripts of MEGPP and MFGP, are less consistent as regards equivalent choice and the limited diversity exhibited therein necessitates more attention.

To begin with $\mathrm{EV}$, the only divergence noted for this text pertains to the renderings of two occurrences of the noun anima, animae 'soul,' which instead of the expected ME soul(e 'soul,' attested in 52 other occurrences of the Latin noun, appear in the text as lif 'life' in these verses. The first attestation of liff (verse 3.2) as a rendering of anima, animae finds no justification context-wise, since in verse 10.1 the noun soul(e is used in a similar environment: compare "Multi dicunt anime <animæ[ae] $>$ mee $<$ mæ[ae] $>^{\prime \prime 19}$ ('Many are saying to my soul' ${ }^{\prime 20}$ ) from verse 3.2 with "quomodo dicitis anime <animæ[ae] $>$ mee <meæ[ae]>" ('How can you say to my soul') of verse 10.1 .

The other occurrence - in verse 7.5 - might be claimed to have been contextually motivated, since anima, animae is personified in this case: it is being pursued and apprehended by enemies, which allows them to "to-trede in the erthe [Psalmist's] lif" ("Persequatur inimicus animam meam \& comprehendat, \& conculcet in terra vitam meam: \& gloriam meam in puluerem < [pulverem] $>$ deducat," 'May an enemy avenge my soul, seize and trample my life in the land, and lead my fame into ashes'). Admittedly, however, verse 7.5 is not the only context in which anima, animae underwent personification - cf. verse 16.11: "Inimici mei animam meam circumdederunt [+super me], adipem suum concluserunt: os eorum locutum est superbiam [superbia]" ('My enemies have surrounded my soul against me. They closed up their fat. Their mouth spoke pride'). Hence, the interpretation might be dubious.

\footnotetext{
${ }^{18}$ It is a term adopted after Charzyńska-Wójcik and Wójcik (2013), and Charzyńska-Wójcik and Charzyński (2014), where such equivalent selection strategy is juxtaposed with dynamic equivalent selection strategy obtaining in the situations where "the item receives different equivalents depending on the context" (Charzyńska-Wójcik \& Charzyński, 2014, p. 87).

${ }^{19}$ Contextual motivation or its lack is evident already upon an examination of the Latin text, for which reason - due to space limitations - I dispense with discussing the ME rendition.

The Latin text used here is the text of the Gallicanum as presented in Charzyńska-Wójcik (2013). Unless stated otherwise, all the quotations provided here and in the remainder of the paper, be they from the Latin text or ME renditions, come from Charzyńska-Wójcik (2013).

${ }^{20}$ All the translations of the Latin text provided in the paper follow Cunyus (2009).
} 
More variation is present in LV, which, unlike in the case of $\mathrm{EV}$, is to be expected as the rendition was intended as a sense-for-sense translation, i.e. a rendition faithful to the source text as far as the sense is concerned, not the form. The divergent cases concern again the renderings of the Latin noun anima, animae, where the two aforementioned nouns - lif and soul(e - are employed, as well as one rendering of the noun cor, cordis 'heart.' To begin with the former, no sound justification for the inconsistent use of lif in the contexts otherwise rendered by soul(e is discernible within the text. Compare the following:

TABLE 2: Divergences in the renderings of anima, animae in LV

\begin{tabular}{|c|c|}
\hline lif & soulle \\
\hline $\begin{array}{l}16.14 \\
\text { eripe animam meam ab impio } \\
\text { 'rescue my soul [...] from the lawless' }\end{array}$ & \begin{tabular}{|l}
6.4 \\
eripe animam meam \\
'[r]escue my soul'
\end{tabular} \\
\hline $\begin{array}{l}21.20 \\
\text { Erue a framea deus [ ] animam meam } \\
\text { 'Rescue my soul from the spear' }\end{array}$ & $\begin{array}{l}32.19 \\
\mathrm{Vt}<[\mathrm{Ut}]>\text { eruat a morte animas eorum } \\
\text { 'that He may rescue their souls from death' }\end{array}$ \\
\hline $\begin{array}{l}34.4 \\
\text { querentes <quæ[ae]rentes> animam meam } \\
\text { 'those seeking my soul' } \\
37.12 \\
\& \text { vim faciebant qui querebant <quæ[ae]rebant> } \\
\text { animam meam } \\
\text { 'Those who were seeking my life caused violence' }\end{array}$ & $\begin{array}{l}39.19 \\
\text { qui querunt <quæ[ae]runt> animam meam } \\
\text { 'who seek my soul' }\end{array}$ \\
\hline $\begin{array}{l}43.27 \\
\text { Quoniam humiliata est in puluere }<\text { [pulvere] }> \\
\text { anima nostra } \\
\text { 'For our soul is humiliated in dust' }\end{array}$ & $\begin{array}{l}34.16 \\
\text { Humiliabam in ieiunio animam meam } \\
\text { 'I humbled my soul in fasting' }\end{array}$ \\
\hline
\end{tabular}

Additionally, I consulted Nicholas of Lyra's (c. 1270-1349) Postilla, a contemporary Psalter Commentary, in search of an external source of motivation for the divergence but only in the case of two of the occurrences in question (30.9 and 43.27) does Lyra's commentary equate anima, animae with vita, vitae 'life': "[a]nimam meam .i. vitam meam" and "anima nostra .i. vita nostra".21

With respect to the divergent rendering of cor, cordis with soul(e, which appears once, in verse 32.15 , it also seems that such a reading might have been motivated by some

\footnotetext{
${ }^{21}$ Interestingly, as pointed out for instance by Alter (2009, pp. xxxii-xxxiii), the Latin noun anima, animae 'soul' - so central to the Psalter - is not in fact a perfect rendering for the Hebrew nefesh 'life breath,' due to the latter's far broader denotatum. In his modern translation from Hebrew, Alter (2009) employs a variety of equivalents for the Hebrew term, ranging from I, through life and being, to belly. Especially interesting in the context of the present paper is the second of the terms, which coincides with EV and LV's divergent readings and might thus be indicative of there being more behind the equivalent selection in Wycliffite translations than meets the eye in a study of such a limited scale.
} 
contemporary commentaries as for instance Lyra's Postilla equates cor, cordis with anima, animae in the exposition on this verse - "cor\|da eorum .i. animas".

On the basis of the above, it can be easily observed that, as mentioned, LV might not be a rendition faithful to Latin to the letter but it is faithful, orthodox, with respect to the meaning. Such an interpretation of the data is corroborated by the fact that the divergences in the renderings of some nouns in LV find motivation, as illustrated, in their contemporary exegetical texts.

Finally, let me turn to the remaining three texts, a close correlation between which allows me to discuss them jointly here. Despite apparent diversification of the renderings of anima, animae, there is in fact only one occurrence of this noun that is of interest for the purposes of this study, since the remaining irregularities are either unanalysable (in each of the Psalters two occurrences of anima, animae are missing) or constitute a reflection of the glossing in the Latin source text: in verse 40.2, in which all the three Psalters diverge from the orthodox reading, the noun is glossed as potestas, potestatis 'power, rule, force' already in the Latin text. The only case of divergence which is thus interesting from the perspective of the present study is the one attested in verse 9.24 in the Dublin manuscript of MEGPP, where anima, animae is rendered as herte (cf. 1 below). As discussed in Lis (2015), a plausible explanation for the divergence might lie in the syntactic and semantic properties of the context in which this particular occurrence of anima, animae is used. To be more precise, among the occurrences of anima, animae, noun-noun structure is observed only in verse 9.24. It is, however, a construction typical of cor, cordis. Additionally, in verse 20.2 (cf. 2) cor, cordis appears in a context analogous to the one in (1) and, what is more, the different versions of the Gallican Psalter exhibit divergence between cor, cordis and anima, animae in this very verse. The close syntactic and semantic similarity between the two contexts might have led the translator to inadvertently replace soul(e with herte, since the text of the whole Psalter must have been well known to him.

(1) 9.24 Quoniam laudatur peccator in desideriis anime/<animæ[ae]>/sue/<suæ[ae]>/: \& iniquus benedicitur.

'Because a sinner is praised in his soul's desires, the treacherous is blessed.'

(2) 20.2 Desiderium cordis [animae] eius tribuisti ei: \& voluntate labi|orum eius non fraudasti eum.

'You have given him his soul's desire, and have not deceived him through his lips' will.' 
As far as the cor, cordis case is concerned, the divergence in verse 36.16 stems, once again, from the glossed nature of the Psalter which in verse 36.16 reads "corda id est animas ipsorum"22 ('their own heart [that is soul] ${ }^{23}$ ). The only other case of variation present in the data from Table 1 are renderings of ren, renis 'kidneys' in the two manuscripts of MEGPP. The divergence does not appear to have been contextually motivated, since ren, renis functions as 'seat of the emotions, passions, heart' in all the three verses in question: "[+et] scrutans corda \& renes deus" ('God is scrutinizing hearts and guts'; 7.10), "vsque $<$ [usque] $>$ ad noctem increpuerunt [increpaverunt] me renes mei" ("[e]ven till night my insides have rebuked me'; 15.7) and "vre <[ure] $>$ renes meos \& cor meum" ('[t]ry my insides and my heart'; 25.2).

Thus, apart from the divergence in the case of ren, renis and the possibly inadvertent replacement of soul(e with herte in verse 9.24 for anima, animae discussed above and despite the apparently complex distribution of the data presented in Table 1, MEGPP appears not to be as extraordinary in this respect as it would seem. It is, in fact, faithful to the source text it renders, whose glossed nature (which it preserves) is a means of adhering to the orthodox reading of the message of the text.

A surprising finding concerning MFGP, despite its apparent diversity in vocabulary selection, is that, apart from the instances of glossing, it does not exhibit any divergences, at least not in the case of the renderings of the four Latin lemmata in question. Therefore, it seems that the rendition should be grouped with RRP and the Montebourg Psalter in this case. It is, however, interesting to notice that it renders both ren, renis and lumbus, lumbi 'loins' with a single French lemma, rein 'kidney.'

\section{Conclusion}

The analysis of the data presented in Section 3, concerning the treatment of the four Latin nouns in the course of their translation leaves no doubt as to the limited character of the divergences in these disparate mediaeval Psalter renditions of the Latin text, at least as far as the notions central to the Psalter are concerned. Two among the studied texts RRP and the 12th-century Anglo-Norman Montebourg Psalter - exhibit no variation in this

\footnotetext{
22 The underlined portion of the text, provided after Black and St-Jacques (2012), represents the gloss.

${ }^{23}$ The rendition of the glossed part, enclosed in square brackets, is my addition.
} 
respect. As I have demonstrated, this also applies to the French counterpart of MEGPP. The sole instances of diversity in equivalent selection are to be noted in the two Wycliffite renditions and MEGPP, and these concern only a handful of cases. For both EV and LV these are the differences in the choice between soul(e and lif as renderings for anima, animae an inconsistency which might have stemmed from the influence of the contemporary exegetical texts, as evidenced by two instances in the case of LV. The only other divergent choice in the equivalent selection for the analysed nouns in LV can also be explained by means of referring to a contemporary exposition. MEGPP, on the other hand, represents the only actual case of divergence - with respect to ren, renis - for which I find no explanation, the single unorthodox rendering of anima, animae by herte in MEGPP D being probably accountable for in the manner suggested in Lis (2015).

Considering a wide variety of contexts in which two of the analysed nouns, i.e. anima, animae and cor, cordis, are attested, the straightforward and almost perfect one-to-one correspondence in their equivalent selection in all the studied renditions appears to be a reflection of the period's approach to biblical translation. The adherence to the source text, though understood and conveyed differently in each of the renditions, is unquestioned. There is no doubt that the mediaeval faithfulness to the original with respect to biblical texts lies at the heart of mediaeval Psalter translations and a practical application of this approach - a reflection of the contemporary attitude to the Bible - apart from its insistence on the straightforward one-to-one correspondence between words in a given verse of the source text and the translation, was their treatment of multiple occurrences of the same lemma. The dominant tendcency in the word-for-word renditions, but noted here also for the more relaxed translations, was to render each such occurrence by means of the same target-language lemma, thus preserving the idea of the one-to-one correspondence between source and target language texts also at the level of lemmata. ${ }^{24}$

\section{References}

Allen, R. S. (1988). Richard Rolle: The English writings. New York, NY: Paulist Press.

Alter, R. (2009). The Book of Psalms: A translation with commentary. New York, NY: W. W. Norton \& Company.

${ }^{24}$ Similar findings are presented in Charzyńska-Wójcik and Wójcik (2013) and Charzyńska-Wójcik and Charzyński (2014). 
Berger, S. (1884). La Bible française au moyen age: étude sur les plus anciennes versions de la Bible écrites en prose de langue d'Oïl. Paris: Imprimerie Nationale.

Black, R., \& St-Jacques, R. C. (Eds.). (2012). The Middle English glossed prose Psalter. Heidelberg: Universitätsverlag Winter.

Bramley, H. R. (Ed.). (1884). The Psalter, or Psalms of David and certain canticles with a translation and exposition in English by Richard Rolle of Hampole: Edited from manuscripts. Oxford: Clarendon Press.

Bülbring, K. D. (Ed.). (1891). The earliest complete English prose Psalter together with eleven canticles and a translation of the Athanasian Creed: Edited from the only two MSS. in the libraries of the British Museum and of the Trinity College, Dublin with preface, introduction, notes and glossary (Pt. 1, Preface and text). London: Kegan Paul, Trench, Trübner \& Co.

Charzyńska-Wójcik, M. (2013). Text and context in Jerome's Psalters: Prose translations into Old, Middle and Early Modern English. Lublin: Wydawnictwo KUL.

Charzyńska-Wójcik, M., \& Charzyński, R. (2014). Listen to the text-on translation strategies in two historical Italian Psalters. In M. Charzyńska-Wójcik, J. Wójcik, \& A. Bloch-Rozmej (Eds.), Language change: Faces and facets (pp. 77-97). Lublin: Wydawnictwo KUL.

Charzyńska-Wójcik, M., \& Wójcik, J. (2013). Principles of equivalent selection in English prose translations of Jerome's Psalters: A study based on 'exaudire' and 'videre'. Roczniki Humanistyczne, 61(5), 27-45.

Copeland, R. (1989). The fortunes of 'non verbum pro verbum': Or why Jerome is not a Ciceronian. In R. Ellis (Ed.), The theory and practice of translation in the Middle Ages (pp. 15-35). Cambridge: D. S. Brewer.

Cunyus, J. G. (2009). The audacity of prayer: A fresh translation of the Book of Psalms (Latin-English edition). Glen Rose, TX: Searchlight Press.

Deanesly, M. (1920). The Lollard Bible and other medieval biblical versions. Cambridge: University Press.

Dictionnaire du Moyen Français, version 2012 (DMF 2012). (n.d.). ATILF - CNRS et Université de Lorraine. Retrieved 2 April 2016, from http://www.atilf.fr/dmf

Dove, M. (2006). Wyclif and the English Bible. In I. C. Levy (Ed.), A companion to John Wyclif (pp.365-406). Leiden and Boston, MA: Brill.

Forshall, J., \& Madden, F. (Eds.). (1850). The Holy Bible, containing the Old and New Testaments, with the apocryphal books, in the earliest English versions made from the Latin Vulgate by John Wycliffe and his followers. Oxford: University Press.

Fowler, D. C. (1960). John Trevisa and the English Bible. Modern Philology, 58(2), 81-98. http:// dx.doi.org/10.1086/389366

Hanna, R. (2003). English Biblical texts before Lollardy and their fate. In F. Somerset, J. C. Havens, \& D. G. Pitard (Eds.), Lollards and their influence in late medieval England (pp. 141-153). Woodbridge: Boydell Press. 
Hargreaves, H. (1965). From Bede to Wyclif: Medieval English Bible translations. Bulletin of the John Rylands Library, 48(1), 118-140.

Histoire de la Bible, Psautier et Apocalypse. (1401-1500). [Middle French Glossed Psalter] MS Bibliothèque nationale fonds française 6260. Retrieved 9 September 2015 from http://gallica.bnf. fr/ark:/12148/btv1b9060447r.r=6260+psautier.langEN

Jerome. (n.d.). De optimo genere interpretandi - A Letter to the Senator Pammachius. Retrieved 2 April 2016, from http://www.newadvent.org/fathers/3001057.htm

Kurath, H., McAllister Kuhn, S., Reidy, J., Lewis, R. E. et al. (Eds.). (1952-2001). Middle English Dictionary. Ann Arbor, MI: University of Michigan Press. Retrieved 9 September 2015 from http://quod.lib.umich.edu/m/med/

Lindberg, C. (1989). The Middle English Bible (Vol. 3, The Book of Judges). Oslo: Norwegian University Press.

Lis, K. (2015). Is there a method in this... madness? - on variance between two manuscript copies of a Middle English Psalter. Linguistics Beyond and Within, 1, 152-168.

Lis, K. (in press). Why differ? - divergent lexical choices in two Middle English prose Psalter translations and their 'raison d'être'. To appear in M. Mamet-Michalkiewicz \& A. AdamowiczPośpiech (Eds.), Translation in culture.

Marsden, R. (2011). The Bible in English in the Middle Ages. In S. Boynton \& D. J. Reilly (Eds.), The practice of the Bible in the Middle Ages: Production, reception and performance in Western Christianity (pp. 272-295). New York, NY: Columbia University Press.

McKinnon, J. W. (1999). The Book of Psalms, monasticism, and the Western liturgy. In N. van Deusen (Ed.), The place of the Psalms in the intellectual culture of the Middle Ages (pp.43-58). Albany, NY: State University of New York Press.

Michel, F. (Ed.). (1876). The Oxford Anglo-Norman Psalter [MS Bodleian Douce 320]. [Montebourg Psalter]. Retrieved 2 April 2016, from http://www.anglo-norman.net/sources/?session=SNW K32162T1441569310

Munday, J. (2009). Issues in translation studies. In J. Munday (Ed.), The Routledge companion to translation studies (revised ed., pp. 1-19). London: Routledge.

Nicholas of Lyra. (1492). Postilla super totam Bibliam. Strasbourg: Johannes Gruninger. Retrieved 2 April 2016, from http://www.umilta.net/nicholalyra.html

Norton, D. (2000). A history of the English Bible as literature. Cambridge: Cambridge University Press. http://dx.doi.org/10.1017/CBO9780511612251

Paues, A. C. (1902). A fourteenth century English Biblical version consisting of a prologue and parts of the New Testament edited from the manuscripts together with some introductory chapters on Middle English Biblical versions (prose-translations). Cambridge: University Press.

Rector, G. (2009). An illustrious vernacular: the Psalter 'en romanz' in twelfth-century England. In J. Wogan-Browne, C. Collette, M. Kowaleski, L. Mooney, A. Putter, \& D. Trotter (Eds.), Language and culture in Medieval Britain: The French of England c.1100-c.1500 (pp. 198-206). York: York Medieval Press. 
Rector, G. (2010). The Romanz Psalter in England and Northern France in the twelfth century: production, mise-en-page, and circulation. Journal of the Early Book Society, 13, 1-38.

Reuter, O. (1938). A study of the French words in the 'Earliest Complete English Prose Psalter'. Societas Scientiarum Fennica: Commentationes Humanarum Litterarum, 9(4).

St-Jacques, R. C. (1989). Middle English Glossed Prose Psalter and its French source. In J Beer (Ed.), Medieval translators and their craft (pp. 135-154). Kalamazoo, MI: Medieval Institute Publications.

Sutherland, A. (2015). English psalms in the Middle Ages, 1300-1450. Oxford: Oxford University Press. http://dx.doi.org/10.1093/acprof:oso/9780198726364.001.0001

Trotter, D. A., Rothwell, W., de Wilde, G., \& Pagan, H. (Eds.). (n.d.). Anglo-Norman Dictionary (2nd ed.). Retrieved 2 April 2016, from http://www.anglo-norman.net/

Van Deusen, N. (Ed.). (1999). The place of the Psalms in the intellectual culture of the Middle Ages. Albany, NY: State University of New York Press.

Wells, J. E. (1916). A manual of the writings in Middle English. 1050-1400. London: Oxford University Press.

Zinn, G. (1999). Introduction. In N. van Deusen (Ed.), The place of the Psalms in the intellectual culture of the Middle Ages (pp. xi-xv). Albany, NY: State University of New York Press.

\section{The soul in the mediaeval Psalter}

The paper is an attempt to examine what lies at the heart and soul of the mediaeval Psalter in the contemporaneous approach(es) to its vernacularisations. In particular, the paper investigates the applications of the mediaeval translation theory in relation to a 12th-century Anglo-Norman, a 15th-century Middle French and four 14th-century Middle English prose Psalter renditions, with a view to locate them within the spirit of the attitude to biblical translations current in the Middle Ages and against the backdrop of the position of the Psalter in the period. In practical terms, the analysis is conducted on the basis of the equivalent selection strategies for rendering four Latin nouns central to the Psalter: anima, animae 'soul,' cor, cordis 'heart' and, perhaps surprisingly, ren, renis 'kidney' and lumbus, lumbi 'loins'. All cases of variation in this respect are studied closely from intra- as well as extra-textual perspectives in order to establish the possible reasons behind the divergences, as these constitute exceptions rather than the rule, even in apparently heterodox renditions.

\section{Keywords:}

biblical translation theory; equivalent selection strategy; Psalter; Psalter translation 


\section{Dusza w średniowiecznym Psałterzu}

Artykuł stanowi próbę bliższego przyjrzenia się podstawowym zasadom średniowiecznego podejścia do tłumaczenia psałterza na języki wernakularne. Przedstawiono w nim analizę zastosowania mediewalnej teorii tłumaczeń w odniesieniu do dwunastowiecznego Psałterza anglo-normandzkiego, piętnastowiecznego Psałterza średniofrancuskiego i czterech czternastowiecznych tłumaczeń Księgi Psalmów na średnioangielski. Celem było wykazanie, w jakim stopniu analizowane teksty odzwierciedlają ówczesne podejście do tłumaczeń biblijnych w kontekście znaczenia psałterza w średniowieczu. Badanie przeprowadzone jest na podstawie doboru ekwiwalentów w tłumaczeniu czterech - niezwykle istotnych z powodu rangi tych tekstów w średniowieczu - łacińskich rzeczowników: anima, animae, 'dusza', cor, cordis, 'serce' oraz, co może zaskoczyć, ren, renis, 'nerka' i lumbus, lumbi, 'lędźwie'. Najwięcej uwagi poświęcono ustaleniu źródła analizowanej z perspektywy zarówno intra-, jak i ekstratekstualnej wariancji w doborze odpowiedników, jako że rozbieżność w tym względzie stanowi raczej wyjątek, a nie regułę, nawet w tłumaczeniach - wydawałoby się - heterodoksyjnych.

\section{Słowa kluczowe:}

teoria tłumaczeń biblijnych; strategia doboru ekwiwalentów; Psałterz; tłumaczenie Psałterza 